\title{
(息)
}

Citation:

Henderson, S (2011) The development of competitive advantage through sustainable event management. Worldwide Hospitality and Tourism Themes, 3 (3). 245 - 257. ISSN 1755-4217 DOI: https://doi.org/10.1108/17554211111142202

Link to Leeds Beckett Repository record:

https://eprints.leedsbeckett.ac.uk/id/eprint/1215/

Document Version:

Article (Submitted Version)

The aim of the Leeds Beckett Repository is to provide open access to our research, as required by funder policies and permitted by publishers and copyright law.

The Leeds Beckett repository holds a wide range of publications, each of which has been checked for copyright and the relevant embargo period has been applied by the Research Services team.

We operate on a standard take-down policy. If you are the author or publisher of an output and you would like it removed from the repository, please contact us and we will investigate on a case-by-case basis.

Each thesis in the repository has been cleared where necessary by the author for third party copyright. If you would like a thesis to be removed from the repository or believe there is an issue with copyright, please contact us on openaccess@leedsbeckett.ac.uk and we will investigate on a case-by-case basis. 
The Development of Competitive Advantage through Sustainable Event Management

Dr. Stephen Henderson

Senior Lecturer

Leeds Metropolitan University

UK Centre for Events Management

Room 216

Bronte Hall

Headingley Campus

Leeds

LS6 3QS

United Kingdom

Email: s.henderson@leedsmet.ac.uk 


\begin{tabular}{|c|c|}
\hline \multicolumn{2}{|l|}{ Abstract } \\
\hline Purpose of this paper & $\begin{array}{l}\text { Whilst the debate rages between } \\
\text { progressive and destructive } \\
\text { considerations of economic } \\
\text { development, this paper aims to } \\
\text { develop thinking around the } \\
\text { sustainable event and its contribution } \\
\text { to competitive advantage. }\end{array}$ \\
\hline Approach & $\begin{array}{l}\text { The paper defines the sustainable } \\
\text { event and considers different position } \\
\text { that might be adopted by private and } \\
\text { public sector organisations when } \\
\text { addressing the triple bottom line of } \\
\text { sustainable development }\end{array}$ \\
\hline Findings & $\begin{array}{l}\text { Cost leadership strategies are } \\
\text { unlikely to work and the event } \\
\text { organiser must address competitive } \\
\text { advantage via differentiation and } \\
\text { focus strategies. }\end{array}$ \\
\hline Research limitations/implications & $\mathrm{N} / \mathrm{A}$ \\
\hline Practical Implications & $\begin{array}{l}\text { Event managers must gain a better } \\
\text { understanding of the motivations of } \\
\text { their audience in relation to } \\
\text { sustainability and work towards } \\
\text { clearer means to demonstrate that } \\
\text { their event meets these sustainable } \\
\text { development needs. }\end{array}$ \\
\hline What is original/value of the article & $\begin{array}{l}\text { The intention being that if event } \\
\text { organisers can see a competitive } \\
\text { advantage in the sustainable event, } \\
\text { their contribution to sustainable } \\
\text { development will be increased. }\end{array}$ \\
\hline
\end{tabular}




\section{The Development of Competitive Advantage through Sustainable Event Management}

\section{Introduction}

To the casual observer, it might appear that economic development across the world is a worthy aim and our ever evolving technology a perfect vehicle to help drive this. As the emergence of new technologies gathered pace in the 60's and 70's, optimistic views suggested that increased leisure time would be a further reward for their increased application. Yet, Toffler (1970) suggested that the increasing rate of change in the technology used would create a stressful society with a 'perception of too much change in a too short period of time'. Forty years later, the dichotomy apparent in this thinking has been fragmented into wide ranging discussion on either side of an argument that sees economic development as either progressive or destructive. For example, Stiglitz (2010) suggests the capitalist process and its related globalisation is simply not a sustainable way forward for the world due to its increasing level of irreplaceable resource utilisation. This parallels the thinking of those who comment on the need for prosperity without growth (Sustainable Development Commission, 2009) calling for non-financial measures of prosperity that have others complaining of social engineering. Furthermore, others argue that the unequal use of depleting resources creates a social inequality with its own set of problems such as poor health or substance abuse (Wilkinson and Pickett, 2009). Saunders (2010) contradicts this, taking the view that the analysis of Wilkinson and Pickett (2009) is superficial and may have a mass of data but uses the extremes for generalisation; is largely based on bi-variant analysis and fails to check for other, confounding variables.

Whilst this debate goes back and forth, the concept of sustainable development (WCED, 1987) has emerged as central to the thinking of any individual or organisation with an eye for global economic development issues. In essence, the concept suggests the need to conserve the resources of the planet, take a fair approach to the people who we contact in our day to day business and make a profit that allows us to continue our activities in the long term. Elkington (1999) suggests that organisations might view this as a concept that requires reporting against a triple bottom line to measure performance in sustainable development terms and transform qualitative thinking into a measurable, quantitative approach. 
Conceptually, sustainable development thinking can be applied across all individual and organisational activity. Indeed, from a global perspective, one might argue that this is a requirement as trade offs between different areas are essential both geographically and commercially. For example, the concept of off-setting our environmental impact has emerged with notional suggestions that the choice of one progressive action may compensate for another, destructive one e.g. that carbon dioxide may be removed from the atmosphere to offset that emitted by travel. Yet, many organisations working at the commodity end of the supply chain would seem to be unable to meet all triple bottom line requirements e.g. oil companies, or, mining companies would seem incapable of directly replacing the specific resources that they take from the planet. On the other hand, 'creative destruction' as observed by Schumpeter (1942), means that the energy derived from oil might be replaced by trading off supply from more sustainable sources such as wind power. Therefore, it is no surprise to find that Nidumolu et al (2009) propose that sustainability must become the key driver of innovation for many organisations. As choices such as those discussed above are not only a matter of debate in terms of their effectiveness but largely voluntary for both organisations and individuals (as opposed to compulsory due to legislation), there is much work required to gain the detailed understanding required to reach global sustainability.

In this paper, the specific area of events and their management is considered including the small scale (such as weddings, business meetings, etc) and the large scale (such as major sports events or cultural gatherings). The latter in particular have already been criticised for their ability to negatively impact the environment by their requirement for large numbers of people to travel long distances and a call to follow a triple bottom line approach (Dwyer, 2005). Furthermore, in terms of the argument that events can positively impact on regional development, Jones $(2005 ; 2008)$ notes that the heterogeneous nature of events means that the local impact of the visitors enjoying the event is a mixed picture. Despite the heterogeneous nature of events, many event organisers have seen fit to state their support of sustainability and process driven standards such as BS8901 in the UK (BSI, 2010) and international environmental standards such as ISO 14001 (ISO, 2010) have been established to guide event industry thinking. However, such standards tend to act as guidelines with limited potential to encourage an organisation's 
sustainable development. Hence, this paper considers how the sustainable development of events can be achieved within the context of competitive advantage. The driver for this line of thinking being that sustainability will be more quickly achieved if an organisation can adopt the sustainable event as a competitive tool in the market.

\section{Aims, Objectives and Approach}

This paper aims specifically to set out a framework that allows those involved in events to consider whether applying sustainable development principles might offer competitive advantage as opposed to sustainable behaviour simply being seen as an accepted cost due to market or legal pressures. Underpinning this overall aim is a number of key objectives that will be addressed by considering the available literature in their respective areas.

These objectives are as follows:

Firstly, to define what is meant by the term 'sustainable event'. Whilst varying views of this might be identified, the aim of this paper can only be achieved if there is a clear framework set by the definition of this term.

Secondly, to examine the role that public and private sector organisations play in sustainable events. The overall aim of the paper has a focus on competitive advantage implying relevance to the market viewpoint of a private sector organisation alone. Though the paper will concentrate on this area, the involvement of the public sector in many events suggests that it is useful to note the viewpoint of the latter. Additionally, the introduction has highlighted the need for a broader view of sustainable development that allows for a balancing across different activities. Hence, it is logical to note the approaches to sustainable development of both sectors as they will be integrated within the same market i.e. pubic sector organised events can use private sector event companies.

Thirdly, to establish what is meant by competitive advantage and to observe the options that can be seen within the context of sustainable events. In doing so, to highlight examples of event organisations with a distinctive approach to sustainability that is gaining a competitive advantage in the market. 


\section{Defining the sustainable event}

The term 'sustainable' is not the only one used when concerns are raised over the abuse of our surroundings in the pursuit of, normally, commercial activity. Terms such as 'responsible', 'greening', 'environmentally friendly', 'corporate social responsibility', 'ecology' and 'eco-friendly' are interchangeably mixed in with 'sustainable'. In considering the 'green' event, Laing and Frost (2010) note the different interpretations and the vagueness of the application of such themes in events. Indeed, casual observation of the publicity surrounding events or the propositions of event management companies will often reveal the use of these terms in simplistic reference to a handful of activities. For example, an event may claim sustainable credentials for its use of locally sourced food and drink even though this represents only a partial consideration of the overall event activity. Whilst activists in sustainability may claim this as progress, others may consider the level of progress as inadequate to meet sustainable development needs and seek more dramatic change.

In considering the idea of a sustainable event (or, indeed, any sustainable activity), the earlier noted definition of sustainable development (WCED, 1987) makes a good starting point for discussion. In essence, it highlights the requirements of organisations that strive to meet their desired objective(s) in a sustainable manner via the application of physical and human resources. This oft quoted definition says that being sustainable requires 'development that meets the needs of the present without compromising the ability of future generations to meet their own needs'. Drawing from the earlier discussion, it becomes clear that many of the aforementioned terms ('greening', etc) tend to emphasise either the 'planet' or 'people' aspect of sustainable development though rarely combine all three sustainable development elements. Here, it's not intended to attempt to define the context of each term as this would be only a matter of semantics. However, it is clear that much of the thinking behind the use of these terms is over simplistic and that all three elements of sustainable development should be addressed by those wanting to manage activities in a sustainable manner.

To take this thinking forward, Hart (1997) argues that multinational organisations need to shift their thinking from 'pollution prevention to product stewardship' i.e. indicating the need to consider a product over the length of 
its life cycle. This proposed shift looks logical to those engaged in the sale of products though it does make assumptions that manufacturing processes are either responsibly managed, or, suitably controlled by legislation. However, a service industry like events management would be well advised to take a wider view of its sustainable development encompassing both the 'product' and 'process' aspects i.e. to organise an event that meets sustainable standards when being enjoyed by its audience but that was irresponsible during set-up or break down would ignore the organisation wide aspects of sustainable development.

Importantly, the proposal from Hart (1997) could be read as suggesting the need for a shift from simple adherence to legislation towards a more ethical viewpoint which opens up the issue of an organisation's motivations. Similarly, reflecting the role of the individual, Laing and Frost (2010) highlight the need 'to explore aspects of behaviour of green event-goers, including their motivations, the influence of their green interest on their decision-making processes with respect to attending events, and their expectations as to the 'green' content of events'. Without doubt, these are valid points for event management to consider and it implies that an event is only sustainable if the attendees choose to behave in a manner supportive of sustainability. Similarly, one could argue that suppliers to events have obligations to behave in a sustainable manner if the event is to have any credibility as being sustainable. For example, recycling waste at an event makes sustainable sense but, perhaps, not if that waste creates further planet problems by being transported some way for the recycling process to happen, or, that cheap labour is required to separate the waste causing people issues. From this, the importance of individual responsibility at the consumer side and organisational responsibility at the supply side of an event can be seen to affect the overall sustainability of an event. Here, it might be noted that one solution on the supply side would be for event managers to contractually oblige suppliers to behave in a sustainable manner. In contrast, many event managers would shy away from being prescriptive about consumer behaviour due to a fear of spoiling their enjoyment or, worse still, losing them as customers. This further emphasises the importance of the suggestion by Laing and Frost (2010) that more research is needed for event managers to understand the event-goer. It is clear, here, that persuading consumers to change behaviour is a tougher prospect than obliging suppliers to behave in the desired manner. 
In conclusion, it is reasonable to reflect that sustainable development definitions offer different dimensions along which a sustainable event might be considered. This being true even if it is accepted that the full process of event management from build to break down is within the definition of a sustainable event. Like other industries, event management needs to make decisions about how to prioritise the triple bottom line elements of planet, people and profit. Furthermore, there is a need to scope the range of sustainable activity associated with the event by consideration of the consumer and supply sides of the event. If both these aspects are clearly defined by the organisation, it becomes clear what is meant by describing an event as sustainable. However, this definition is specific to the event and organisations leaving limited means of comparison between events until clear standards are laid down by legislation or other policy making outputs such as quantified standards.

\section{The roles of pubic and private sector organisations in events}

As stated earlier, the notion of competitive advantage suggests a private sector view that looks to maximize profits by outperforming competitors as opposed to the public sector where non-profit objectives are more often the goal. However, in appreciating the nature of the sustainable event, it is worth considering the purpose behind both private and public sector organised events.

The public sector plays two roles in the events industry. Firstly, government at national level or councils at local level may help support event infrastructure by way of managing venues covering the social, cultural and sporting needs of the population. The extent of this depends on the policy adopted in that area and how the line is drawn between public sector support and private sector entrepreneurialism. Secondly, the public sector uses events to have impacts in financial, cultural or social terms. In a financial sense, this is the indirect supporting of business where (a programme of) events can be used to boost tourism or other inward investment. Cultural impacts are often aimed at boosting the cultural image of the area as part of their destination marketing or as a means to entertain local minority communities. Social impacts include the integration of different communities or making available certain experiences for deprived communities. Looking at larger events such as the Olympics, these are seen to endeavour to meet a combination of these impact 
objectives. The key lesson to learn from this is that the overriding point to these public sector events is one of investing to have impact. Consequently, well organised public sector events have clear impact objectives and can measure the outcomes against these to justify their investment in the event(s). Turning to the private sector, events are used to satisfy the needs of customers in exchange for payment to achieve profits and can be split into three categories. Firstly, there are events that are satisfying the needs of the consumer (business to consumer, B2C). Secondly, other events are satisfying the needs of the corporation (business to business, B2B). Finally, generally smaller, events exist to satisfy the needs of the private individual with friends and family e.g. in celebration of a birthday, or, wedding. In terms of organisations offering these events, there are both the full service event management companies and those specialists who concentrate in supplying part of the event e.g. venue hire or catering. All these organisations have traditionally measured success in the form of financial returns achieved by having some form of competitive advantage that has translated into customer value.

\section{Take in Fig. I Sustainable Development}

If the earlier sustainable development model is used to generate the different positions that might be adopted (Figure I), it can be seen that public and private sector organisations have a range of choices. Both types of organisation can operate within areas that are financially sustainable as their existence is guaranteed even if they are not meeting 'people' and/or 'planet' objectives. Yet, whilst a public sector organisation with supportive funding may act in the financially unsustainable areas as it pursues cultural or social impacts, a private sector organisation would face bankruptcy if following the same path. Hence, the private sector must meet financially sustainable objectives and, clearly, this position affects the private sector prioritisation of the triple bottom line. Figge et al (2002) suggest that if an organisation wishes to address the triple bottom line in a planned way, it should consider the application of a sustainability based balanced scorecard. This latter concept was introduced by Kaplan and Norton (1996) as a tool that allows for the management of 'soft' factors such as human resources or customer satisfaction. Hence, Figge et al (2002) propose that this concept allows planet and people to be considered alongside the 'hard' factors of key profit accounting measures. Similarly, Mair and Jago (2010) offer a model of drivers 
and barriers for corporate greening in the business events sector which highlights the factors that will influence an organisation's choice ranging between 'very green' and 'not green at all'. Whilst this latter model uses the term 'green', many of its principles can be applied across the triple bottom line elements of sustainable development.

At a strategic level in the public sector, Getz (2009) has argued that there is a need for a paradigm shift towards sustainability in event policy. This reflects the preceding discussion where Hart (1997) calls for a shift in thinking towards product stewardship. Dredge and Whitford (2010) in response to Getz suggest the need for 'a more nuanced understanding in order to account for, and accommodate, the intricacies pertaining to events and event policy'. The ideas coming from Dredge and Whitford (2010) align with the earlier developed definition of a sustainable event indicating the need to scope the event in terms of addressing the sustainability impacts of both the event-goer and the suppliers to the event. Indeed, developing the approach of Dredge and Whitford (2010) suggests adding the wider range of stakeholders that can be involved in events (e.g. the local community) and, thereby, widens the earlier consideration of the scope of the sustainable event. These viewpoints contribute to the intellectual arguments surrounding events policy and highlight how the approach of the public sector overlaps with private sector events based businesses in reflecting the need to scope sustainable activities. Sadly, the evidence of the past shows that the events industry has tended to implement strategic level policy change when driven by new legislation as opposed to doing this on a voluntary basis. Having learnt from death and disaster at, for example, Bradford City Football Club (Hansard, 1986) and Hillsborough (Hansard, 1990), changes have resulted in health and safety legislation aimed at protecting all those gathered at events. From these disasters, new approaches to stadium design, crowd management and fire safety were established within UK law and wider guidance. Similarly, deaths at Roskilde (Kultur Ministeriet, 2010) brought about reviews of health and safety legislation in Denmark. Consequently, it might be assumed that there is little else other than legislation that might drive the events industry to look at the wider issues of sustainability. So, to encourage sustainable development, organisations will depend on their customers having a positive disposition to sustainability i.e. to have event-goers who value sustainability. So, to progress sustainability in events, the event managers need to identify routes to competitive advantage that involve sustainable events. 
Take in Fig. II Narrowed sustainable event management options in the private sector

Bringing together the aforementioned definition of a sustainable event and the approaches to sustainability seen in Figure I, those areas that are financially unsustainable may be ignored as options for the private sector due to profit being required for the survival of the organisation. Hence, sustainable development positions that might be adopted by event management businesses in the private sector are limited to those seen in Figure II:

The profiteer - whilst the traditional view of the term profiteering as an unethical approach to business may be rather harsh, this is the basic approach to an event with no interest in sustainability other than making a sustainable profit. Consequently, this option really offers no means to consider sustainable events as a source of competitive advantage due to the sole emphasis on profit.

The socially conscious and The environmentally conscious - those who seek sustainability in both the profit and people areas of event management may be seen as the socially conscious whilst, similarly, those who seek sustainability in both the profit and planet areas of event management take an environmentally conscious approach. Event management companies may adopt two typical opposing positions in these areas reflecting the emphasis on the distribution of profit to shareholders or in support of people and planet objectives. The former, the event based organisation that emphasises people or planet driven objectives as a central part of their sales proposition and often as a non-profit organisation e.g. some festivals with a significant green agenda (Peats Ridge Festival, 2010), or, directly, to use events to fundraise for charities supporting people or planet. The latter, those event companies that adopt people or planet concerns as part of corporate social responsibility whilst keeping profit for shareholders as their main objective.

The fully sustainable - these are organisations that seek profit but take up concerns about people and planet in roughly equal measure. Here, we might also consider that there is a range of activity combining those described as the socially or environmentally conscious. 
In summary, the private sector event related business that might seek competitive advantage using sustainable events will do so from a sustainable profit position with people and/or planet objectives as part of its aims too. However, some may seek to emphasise profit for shareholders whilst others may use their profit to support people and/or planet objectives in a non-profit organisation such as a charity.

\section{Competitive Advantage in Sustainable Events}

So, having identified the different positions that might be adopted by event companies seeking a sustainable approach to their organisation, it remains to identify how these positions might be translated into competitive advantage. Porter (1985) defines competitive advantage along the three dimensions of cost, differentiation and focus with competitors trying to set themselves apart from those perceived as 'stuck in the middle' without competitive advantage. Porter's work suggests that being able to produce an event at a lower cost than the competitors is one way to competitive advantage. Typically, this comes from large scale organisations developing efficiency due to their repetitive experience of the tasks involved or using their power to leverage lower costs from suppliers. The other two routes to competitive advantage relate to the value seen by customers who either see specific attractive elements in the offering (differentiation) or feel that all their needs are being met in the best way by that competitor's offering (focus). It would be unusual to find an organisation that competes on all three dimensions but most would hope to have competitive advantage from one or other dimension.

Cost based competitive advantage requires actions that specifically reduce costs to a level lower than competitors which generally requires the scale economies that come with large market share in a growing market. Hence, there are elements in cost competition that conflict with the commentators who suggest that sustainable development is best met by providing prosperity without growth (Sustainable Development Commission, 2009). On the other hand, there are elements in events management where costs can be reduced in the pursuit of sustainable practice. For example, waste from events might be buried in landfill by the local authorities at a cost to the company. So, any efforts to encourage stakeholders at the event to behave sustainability and reduce waste will reduce costs i.e. even without considering the competitive advantage of being the overall cost leader, an event management company 
may increase profits by encouraging less waste. In contrast, more planet friendly sources of energy such as bio-fuels may be seen as expensive and work against achieving cost based competitive advantage. Similarly, saving costs on employing people by using volunteers, etc may be perceived as not following sustainable development principles supportive of people elements. Overall, event managers are likely to be limited in their ability to use sustainable event attributes as a route to the cost based competitive advantage of a cost leader.

Differentiation based competitive advantage suggests that the sustainable event offers a means to look different from competitors. This can be the case where specific products or services offered within an event have distinctive people or planet elements. For example, The Green Tent Company offers festival-goers a product that can be purchased, used and recycled at the end of the festival (The Green Tent Company, 2010). This distinct approach offers an event product that is seen to clearly differ from its non-recyclable competitors and, hence, is seen as of value to the consumer with a more environmentally aware perspective. Of course, there is an assumption here that a proportion of event-goers are positively pre-disposed to these products and, as earlier suggested by Laing and Frost (2010), this is an area that requires investigation.

If the overall event is considered for its potential to be differentiated as sustainable, this requires a return to consideration of what makes a sustainable event i.e. based on the earlier scoping proposition to consider the extent to which the triple bottom line and all stakeholders are considered. As noted earlier, event organisers have many choices in terms of how they position themselves along these dimensions. Ideally, establishing a differentiated position is driven by standards and the ability for events to be accredited against those standards. The Global Reporting Initiative (Global Reporting Initiative, 2010a) is developing standard procedures for selfreporting against sustainable development goals. Their work addresses any organisation that wishes to engage with such aims and its overall view of relevant activities to be addressed is summarised by their quick reference sheet (Global Reporting Initiative, 2010b) and the current state of voluntary and mandatory reporting captured in an output from their 2010 conference (Global Conference on Sustainability and Transparency, 2010). UK standards such BS8901 (BSI, 2010) are specific to events but largely address the 
process being followed and not the outcomes of the process though BSI has superseded their process of self-certification with a mechanism that allows organisations to be assessed and certified against BS8901. In this way, event managers are being offered the opportunity to differentiate their organisation from others by gaining this accreditation. Similarly, event organisations such as Festivals Edinburgh are working together to benchmark their activities and identify ways that allow them to make their events more sustainable (Festivals Edinburgh, 2010). The extent to which publicity around accreditation or similar benchmarking exercises allows differentiation will depend on the perceived quality of the standards and the reporting against them. Where the quality is seen to be of a high standard, consumer perception will be that of a differentiated offering provided other competitor events are not similarly accredited.

Focus based competitive advantage occurs where the event organiser targets consumers who already wish to act in a sustainable manner and are predisposed to people and planet sustainability. There has been a range of work emerged covering the sociology of consumption and its links through to sustainability. For example, based on studying a student population, Straughan and Roberts (1999) suggest three psychographic predictors of 'green' consumer behaviour: perceived consumer effectiveness; altruism and political liberalism. Whilst others look at the impact of demographics such as gender (MacDonald and Hara, 1994) or race (Murphy et al, 1978) on green attitudes, McDonald et al. (2006) consider the lifestyle of 'voluntary simplifiers' who are individuals freely selecting a life that is frugal, anti-consumer, low in resource use and environmental impact. For the event organiser, it becomes clear that there is a segment of the market that might be targeted based on their pre-disposition to sustainability but that there is a need to better understand that audience as indicated earlier by Laing and Frost (2010). Indeed, at one extreme, it might be argued that 'voluntary simplifiers' might see involvement with major events as activity that does not fit their lifestyle. Elsewhere, determining its value in any particular event market (e.g. conferences versus festivals, heavy metal versus classical concerts, etc) is a task required of each event organiser as most events will attract a different audience. 


\section{Conclusion}

This paper sets out to identify a framework that allows those involved in events to consider whether applying sustainable principles might offer competitive advantage. Though largely a conceptual discussion, a number of conclusions have been drawn:

\section{- The lack of a single definition of a sustainable event}

Consideration of what defines a sustainable event has revealed that those involved in the industry have choices along two dimensions when considering the scoping of the sustainability of their events. Firstly, to what extent the objectives of the organisation address the triple bottom line of profit, planet and people. Secondly, to what extent they consider the sustainability issues surrounding the activities of all the stakeholders involved in the event.

\section{- Public sector events may adopt sustainable event policies}

In the area of public events, there appears to be an increased call to shift the event paradigm towards one that is more truly sustainable (Getz, 2009) alongside recognition of the complexity in this area (Dredge and Whitford, 2010) as reflected in the lack of a single definition of sustainability. However, adopting sustainable event policies will depend on a supportive political imperative.

- Private sector events seek profit from competitive advantage ahead of the other planet and people sustainable elements

In the private sector, organisations will prioritise profit above planet and people due to the need to survive in a competitive environment. Those wishing to integrate the triple bottom line will need to establish concepts such as the sustainability balanced scorecard (Figge et al., 2002) to allow for planet and people objectives.

- Competitive advantage from sustainable events is less likely from cost leadership strategies

Given that sustainable alternatives for many activities have a higher cost, it seems unlikely that the cost leadership generic strategy of Porter (1985) is feasible using sustainable events. However, though a cost based approach may not offer competitive advantage, there is scope for event organisers to reduce costs by adopting certain activities, particularly, where legislation 
means that a lack of adoption of sustainable approaches such as recycling are punished by higher costs or fines.

- Differentiation and focus based competitive advantage from sustainable events require a better understanding of the consumer and clarity of the benefits accrued from the approach

Both differentiation and focus routes to competitive advantage are feasible using sustainable events. However, both approaches require the organisation to establish means to identify the attitudes towards sustainability in their target market and to be able to be clear about how the event is meeting using sustainability standards and other mechanisms to communicate the success of their sustainable actions.

\section{Further work}

For many activists operating in the area of sustainability, the approaches are seen as incremental in nature addressing individual activities one at a time. However, to make step changes towards a sustainable event industry without legislation, this paper suggests that the strong leadership required to achieve sustainable development must identify the value that an audience recognises in a sustainable event and improved ways of demonstrating sustainable performance. Clearly, the two key areas for further effort are improved understanding of the sustainable development related motivations of event audiences and clarity to how their sustainable event needs are met. 


\section{References}

BSI (2010) BS 8901Sustainability Management Systems for Events. Available from: <http://www.bsigroup.co.uk/en/Assessment-and-Certificationservices/Management-systems/Standards-and-Schemes/BS-8901/> [Accessed 12 December 2010].

Dredge, Dianne and Whitford, Michelle (2010) Policy for sustainable and responsible festivals and events: institutionalisation of a new paradigm - a response. Journal of Policy Research in Tourism, Leisure and Events, Volume 2, Issue 1, pp 1-13.

Dwyer, L. (2005). Relevance of triple bottom line reporting to achievement of sustainable tourism: a scoping study. Tourism Review International, Volume 9, 1, pp 79-93.

Elkington, John (1999). Cannibals with Forks: Triple Bottom Line of 21st Century Business. Oxford, Capstone Publishing.

Figge, F., Hahn, T., Schaltegger, S. and Wagner, M. (2002) The Sustainability Balanced Scorecard. Linking sustainability management to business strategy. Business Strategy and the Environment, 11, pp 269-284.

Festivals Edinburgh, (2010) Available from:

<http://www.festivalsedinburgh.com/blog-environmental-sustainability> [Accessed 12 December 2010].

Getz, Donald (2009) Policy for sustainable and responsible festivals and events: institutionalization of a new paradigm. Journal of Policy Research in Tourism, Leisure and Events, Vol. 1, No. 1, March, pp 61-78.

Global Reporting Initiative (2010a) Available from:

<http://www.globalreporting.org/Home> [Accessed 12 December 2010].

Global Reporting Initiative (2010b) Available from:

<http://www.globalreporting.org/NR/rdonlyres/DDB9A2EA-7715-4E1A-9047FD2FA8032762/0/G3_QuickReferenceSheet.pdf> [Accessed 12 December 2010]. 
Global Conference on Sustainability and Transparency (2010). Available from: <http://www.globalreporting.org/NewsEventsPress/ConferenceAndEvents/Co nference2010.htm $>$ [Accessed 12 December 2010].

Hansard (1986) Popplewell Final Report. Available from:

<http://hansard.millbanksystems.com/lords/1986/jan/16/popplewell-finalreport> [Accessed 12 December 2010].

Hansard (1990) Hillsborough Disaster: Inquiry Report. Available from: <http://hansard.millbanksystems.com/lords/1990/jan/29/hillsborough-disasterinquiry-report> [Accessed 12 December 2010].

Hart, Stuart L. (1997) Beyond Greening - Strategies for a Sustainable World, Harvard Business Review, January, pp 66-76.

ISO (2010) ISO 14000 essentials. Available from: <http://www.iso.org/iso/iso_14000_essentials> [Accessed 12 December 2010].

Jones, Calvin (2005) Major events, networks and regional development. Regional Studies, 39: 2, pp 185-195.

Jones, Calvin (2008) Assessing the impact of a major sporting event: the role of environmental accounting. Tourism Economics, 14 (2), pp 343-360.

Kaplan, Robert S. and Norton, David P. (2006) Translating Strategy into Action - The Balanced Scorecard. Boston, Harvard Business School Press.

Kultur Ministeriet (2010) Rock Festival Safety. Available from:

<http://kum.dk/Documents/Publikationer/2001/Rock\%20Festival\%20Safety/ro ck_festival_safety.pdf> [Accessed 12 December 2010].

Laing, Jennifer and Frost, Warwick (2010) How green was my festival: Exploring challenges and opportunities associated with staging green events. International Journal of Hospitality Management. Volume 29, Issue 2, June, pp 261-267 
Mair, J. and Jago, L.(2010).The Development of a Conceptual Model of Greening in the Business Events Tourism Sector", Journal of Sustainable Tourism, Vol.18 (1), pp 77-94.

MacDonald, W.L. and Hara, N. (1994) Gender differences in environmental concern among college students'. Sex Roles, Volume 33, No. 5/6, pp 369-74.

McDonald, Seonaidh, Oates, Caroline J.,Young, C. William, Hwang and Kumju (2006) Toward sustainable consumption: Researching voluntary simplifiers. Psychology and Marketing, Volume 23, Issue 6, pp 515-534.

Murphy, P.E., Kangun, N. and Locander, W.B. (1978) Environmentally concerned consumers - racial variations. Journal of Marketing, Volume 54, October, pp 61-6.

Nidumolu, R., Pralahad, C.K. and Rangaswami, M.R. (2009), Why Sustainability Is Now The Key Driver Of Innovation, Harvard Business Review, September, pp 56-64.

Peats Ridge Festival (2010) Peats Ridge Glenworth Valley Sustainable Arts and Music Festival. Available from: <http://www.peatsridgefestival.com.au/ > [Accessed 12 December 2010].

Porter, Michael (1985) Competitive Advantage. New York, The Free Press.

Saunders, Peter (2010), Beware False Prophets - Equality, the Good Society and The Spirit Level. Available from:

$<$ http://www.policyexchange.org.uk/assets/Beware_False_Prophets_Jul_10.p df $>$ [Accessed 12 December 2010].

Schumpeter, Joseph A. (1942) Capitalism, Socialism and Democracy. $3^{\text {rd }}$ Edition. Harper \& Brothers, New York.

Stiglitz, Joseph (2010) Freefall: Free Markets and the Sinking of the Global Economy. London, Penguin.

Straughan, Robert D. and Roberts, James A. (1999) Environmental 
segmentation alternatives: a look at green consumer behavior in the new millennium. Journal of Consumer Marketing, Vol. 16, Issue 6, pp.558 - 575

Sustainable Development Commission (2009) Prosperity without Growth? Available from: <http://www.sd-commission.org.uk/pages/redefiningprosperity.html > [Accessed 12 December 2010].

The Green Tent Company, (2010). Available from:

<http://www.thegreententcompany.co.uk/> [Accessed 12 December 2010].

Toffler, Alvin (1970) Future Shock. $1^{\text {st }}$ Edition. New York, Random House.

WCED (1987). Our Common Future. World Commission on Environment and Development, Oxford, Oxford University Press.

Wilkinson, Richard and Pickett, Kate (2009) The Spirit Level: Why More Equal Societies Almost Always Do Better. London, Penguin. 